\title{
Potential role of ticks as vectors of bluetongue virus
}

\author{
Chantal Bouwknegt • Piet A. van Rijn • Jacqueline J. M. Schipper • \\ Dennis Hölzel • Jan Boonstra • Ard M. Nijhof • Eugène M. A. van Rooij • \\ Frans Jongejan
}

Received: 22 February 2010/ Accepted: 8 March 2010/Published online: 1 April 2010

(C) The Author(s) 2010. This article is published with open access at Springerlink.com

\begin{abstract}
When the first outbreak of bluetongue virus serotype 8 (BTV8) was recorded in North-West Europe in August 2006 and renewed outbreaks occurred in the summer of 2007 and again in 2008, the question was raised how the virus survived the winter. Since most adult Culicoides vector midges are assumed not to survive the northern European winter, and transovarial transmission in Culicoides is not recorded, we examined the potential vector role of ixodid and argasid ticks for bluetongue virus. Four species of ixodid ticks (Ixodes ricinus, Ixodes hexagonus, Dermacentor reticulatus and Rhipicephalus bursa) and one soft tick species, Ornithodoros savignyi, ingested BTV8-containing blood either through capillary feeding or by feeding on artificial membranes. The virus was taken up by the ticks and was found to pass through the gut barrier and spread via the haemolymph into the salivary glands, ovaries and testes, as demonstrated by real-time reverse transcriptase PCR (PCR-test). BTV8 was detected in various tissues of ixodid ticks for up to 21 days post feeding and in Ornithodoros ticks for up to 26 days. It was found after moulting in adult Ixodes hexagonus and was also able to pass through the ovaries into the eggs of an Ornithodoros savignyi tick. This study demonstrates that ticks can become infected with bluetongue virus serotype 8 . The transstadial passage in hard ticks and transovarial passage in soft ticks suggest that ticks have potential vectorial capacity for bluetongue virus.
\end{abstract}

C. Bouwknegt · J. J. M. Schipper · A. M. Nijhof · F. Jongejan

Utrecht Centre for Tick-borne Diseases (UCTD), Department of Infectious Diseases and Immunology, Faculty of Veterinary Medicine, Utrecht University, Yalelaan 1, 3584CL Utrecht, The Netherlands

P. A. van Rijn · D. Hölzel · J. Boonstra · E. M. A. van Rooij

Department of Virology, Central Veterinary Institute (CVI) of Wageningen UR, PO Box 65, 8200 AB Lelystad, The Netherlands

Present Address:

E. M. A. van Rooij

Central Laboratory Animal Research Facility, Faculty of Veterinary Medicine, University Utrecht, P.O. Box 80190, 3508 TD Utrecht, The Netherlands

F. Jongejan ( $₫)$

Department of Veterinary Tropical Diseases, Faculty of Veterinary Science, University of Pretoria, Private Bag X04, Onderstepoort, Pretoria 0110, South Africa

e-mail: F.Jongejan@uu.nl 
Further studies are required to investigate transmission from infected ticks to domestic livestock. This route of transmission could provide an additional clue in the unresolved mystery of the epidemiology of Bluetongue in Europe by considering ticks as a potential overwintering mechanism for bluetongue virus.

Keywords Ticks · Bluetongue virus · Artificial infection · In vitro feeding

\section{Introduction}

Bluetongue is a non-contagious infectious disease transmitted by the bites of Culicoides midges and affects domestic livestock with clinical signs ranging from apathy and weight loss to swollen heads, tender feet and death (Verwoerd and Erasmus 2004). Bluetongue virus (BTV) is a double stranded RNA-virus, belonging to the genus Orbivirus of the family Reoviridae with 24 different known serotypes (Verwoerd and Erasmus 2004; Mellor and Boorman 1995). In August 2006, bluetongue virus serotype 8 (BTV8) emerged and spread rapidly in North-West Europe through local vectors (Enserink 2006), and clinical cases disappeared in early January 2007. The re-emergence of the outbreak many months later affected a large number of holdings and clearly demonstrated that BTV8 had somehow survived the winter. This most economically damaging outbreak of bluetongue ever seen came to a halt towards the end of 2007. In the summer of 2008 new outbreaks of BTV8 occurred again in large parts of North-West Europe(Schwartz-Cornil et al. 2008). The ability of BTV to "overwinter" has been recognised for decades in other parts of the world (Nevill 1971). In South-Africa transmission is interrupted when both Culicoides midge activity as well as virus replication in the vector midge ceases at cool temperatures (Nevill 1971). However, if outbreaks resume only after several months, far longer than the lifespan of the local adult Culicoides vector or the duration of viraemia in the mammalian host, the question is raised where the virus persists without detection during the winter months (Wilson et al. 2008).

Of the indigenous European Culicoides species, principally Culicoides dewulfi, species of the obsoletus complex and Culicoides chiopterus, are considered to be the main vectors of BTV8 (Nevill 1971; Wilson et al. 2008). Although it is assumed that BTV is unable to survive when most adult midges succumb during the North-West European winters, its overwintering ability may be enhanced in the local vectors (Dijkstra et al. 2008; Meiswinkel et al. 2007). Alternatively, because most species of Culicoides at northern latitudes survive the winter as larvae, it might appear that the most likely mechanism for overwintering is the vertical transmission of virus from infected vectors to offspring via the developing egg. However, experiments designed to look for vertical transmission of BTV in Culicoides have consistently given negative results (Mellor 1990).

Even if BTV may persist in local vectors or in various mammalian hosts, alternative vectors could also play a role. For instance, mechanical transmission of BTV has been reported in Melophagus ovinus, a wingless fly that lives in the fleece of sheep (Luedke et al. 1965).

Ticks have a much longer lifespan than Culicoides midges, and may also act as biological vectors of BTV. Interestingly, the vectorial capacity of the American soft tick Ornithodoros coriaceus for BTV has already been reported in 1985 (Stott et al. 1985). O. coriaceus ticks could become infected by feeding through an artificial membrane on BTV-containing cell culture material or on BTV-containing sheep blood. The ticks were also infected by feeding on viraemic sheep or cattle. It was also possible to transmit BTV 
to cattle by soft ticks after feeding on BTV-containing cell culture material (Stott et al. 1985).

Ticks have a relatively long lifespan. Ixodes ricinus, the predominant ixodid tick in North-West Europe, feeds on a broad range of hosts including domestic ruminants and takes two to three years to complete its lifecycle. As a typical three-host tick, I. ricinus feeds in total approximately 3 weeks divided over three different hosts. The remaining time is spent in the vegetation. Other ticks, such as Dermacentor species complete one generation per year. The feeding behaviour of ticks on viraemic hosts on the one hand and the long-term survival of ticks off-host on the other hand, makes ticks excellent candidates to serve as viral reservoirs. In fact, there are many other viruses belonging to the genus Orbivirus, which are transmitted by ticks (Labuda and Nuttall 2004).

The objective of this work was to explore the potential role of European ticks as vectors of BTV8. To this end, four species of ixodid (hard) ticks, I. ricinus, Ixodes hexagonus, Dermacentor reticulatus, and Rhipicephalus bursa, were artificially infected with BTV8 containing blood through capillary feeding, in order to determine whether the virus could be maintained in these tick species. Moreover, I. ricinus ticks and the soft tick Ornithodoros savignyi were infected with BTV8 containing blood by feeding on artificial membranes.

\section{Materials and methods}

Ticks

Both hard (Ixodidae) and soft (Argasidae) ticks were used in this study. Three species of ixodid ticks were selected on the basis of their feeding preferences for livestock prevalent in North-West Europe (Estrada-Peña et al. 2004). The most commonly found tick I. ricinus feeds on a broad range of hosts including cattle, sheep and goats (Estrada-Peña et al. 2004). Adult ticks used in this study originated from the vegetation at different locations in the province of Utrecht in the Netherlands. Ixodes hexagonus, a tick commonly found on hedgehogs but also on domestic animals, was obtained from a laboratory colony maintained at the Utrecht Centre for Tick-borne Diseases (UCTD) and originated from an engorged female tick collected from a dog. Dermacentor reticulatus adults and nymphs were also available from the UCTD colonies. These ticks originated from the vegetation in the South-West of the Netherlands, where this tick had recently been discovered (Nijhof et al. 2007). Dermacentor reticulatus feeds on a range of different hosts, including cattle, small ruminants and companion animals and occurs in typical habitats in much of Europe (Estrada-Pena et al. 2007). Furthermore, R. bursa, a two host tick widely distributed on cattle, sheep and goats in southern Europe, was also used in the experiments and was obtained from a laboratory colony of UCTD. In addition, the soft tick $O$. savignyi was used as a control in the sense that previous studies had already shown that Ornithodoros ticks are able to transmit BTV to cattle (Stott et al. 1985). Ornithodoros savignyi originated from a laboratory colony maintained at the University of Pretoria in South Africa. This tick does not occur in Europe, but is found on domestic animals in semi-arid regions of Southern and Eastern Africa (Hoogstraal 1956).

Laboratory-reared negative control ticks, never exposed to BTV8 and artificial feeding, were also included in each of the experiments described below. 
BTV

Bluetongue virus serotype 8 was used to spike blood collected in heparin from a calf negative for BTV and BTV-antibodies. The blood was divided into $1 \mathrm{ml}$ aliquots and stored at $-80^{\circ} \mathrm{C}$ until used in the experiments.

\section{Capillary feeding of ixodid ticks}

Capillary feeding of different ixodid tick species has been reported and has also been applied to in vitro acquisition of pathogens by ticks (Burgdorfer 1957; Matsumoto et al. 2005; Rechav et al. 1999; Booth et al. 1991; Inokuma and Kemp 1998). In brief, four species of ixodid ticks were fed on a capillary, after feeding for 3 days on a rabbit. They were removed with forceps from the rabbit and placed on sticky tape with their ventral side facing upwards. BTV8-containing blood was thawed and heated to $36^{\circ} \mathrm{C}$. A capillary was placed over the hypostome of adult ticks and, in the case of nymphs, the hypostome as well as one palp was inserted into the capillary. Subsequently, each capillary was filled with viraemic blood and attached to the tick with adhesive tape. Ticks and capillaries were incubated overnight at $37^{\circ} \mathrm{C}$ and $85 \%$ relative humidity. Thereafter, capillaries were carefully removed and the ticks were placed in an incubator at $27^{\circ} \mathrm{C}$ and $85 \%$ relative humidity. Several female ticks were allowed to lay eggs. All ticks were weighed before and after the capillary feeding in order to estimate the amount of ingested blood.

\section{Membrane feeding of ixodid ticks}

Voluntary feeding of ticks on artificial membranes mimics the natural feeding behaviour better than forced capillary feeding. Therefore, adult I. ricinus female ticks, partially fed for 4 days together with male ticks on a rabbit, were placed into a feeding unit consisting of a silicone-impregnated membrane as described by Kröber and Guerin (Kröber and Guerin 2007). Each feeding unit was placed into a well of a six-well plate containing BTV8-containing blood kept at $36^{\circ} \mathrm{C}$ during the feeding process. The blood was replenished every $12 \mathrm{~h}$ and $I$. ricinus females fed for $44 \mathrm{~h}$ after attachment until repletion.

Membrane feeding of argasid ticks

Adult $O$. savignyi ticks were allowed to engorge on an artificial membrane consisting of Parafilm ${ }^{\circledR}$ according to methods described by Schwan et al. (1991). The viraemic blood under the membrane was kept at a constant temperature of $36^{\circ} \mathrm{C}$ during the feeding process. Thereafter, ticks were weighed and placed in an incubator at $28^{\circ} \mathrm{C}$ and $80 \%$ relative humidity. Several female ticks were allowed to lay eggs.

\section{Tick dissection}

Ixodid ticks were dissected on various days post-feeding under ice-cold phosphate buffered saline (PBS), ventral side upwards and fixed with forceps in a small Petri dish. A transverse incision was made between coxa 2 and 3 and the salivary glands, gut, ovaries or testes, Malpighian tubules and remaining tissue were removed, washed in ice-cold PBS and stored in different vials, which were frozen in liquid nitrogen and stored at $-80^{\circ} \mathrm{C}$ until processed by real time RT-PCR. 
Soft ticks were fixed in a paraffin-containing Petri dish with their dorsal side upwards and dissected under ice-cold PBS. A circular incision was made to remove the dorsal part of the integument. Salivary glands, guts, ovaries, Malpighian tubules and remaining tissue were removed, washed in ice-cold PBS, frozen in liquid nitrogen and stored at $-80^{\circ} \mathrm{C}$ in separate vials.

Furthermore, eggs, ixodid larvae and argasid $\mathrm{N}_{1}$ nymphs were also frozen into liquid nitrogen and stored at $-80^{\circ} \mathrm{C}$ until processed by real time RT-PCR.

\section{Real-time RT-PCR}

Various tissues dissected from the ticks as well as tick eggs, larvae and nymphs were tested for the presence of BTV8 by the real-time reverse transcriptase PCR assay (PCR-test). Briefly, viral dsRNA from $200 \mu$ diluted (1:1 with PBS) tick sample was isolated using the Total Nucleic Acid Isolation Kit (Roche Diagnostics Nederland, Almere, Netherlands) using an isolation robot MagNa Pure (Roche Diagnostics Nederland) according to the instructions of the manufacturer. Isolated dsRNA samples were tested using primers (Eurogentec Nederland, Maastricht, Netherlands) and a Taqman probe (Tib MolBiol, Berlin, Germany) targeting segment 10 of the BTV genome. Real-time reverse transcriptase PCR was performed with a LightCycler RNA Master Hybridization Probes kit in a LightCycler 2.0 (Roche Diagnostics Nederland). Template RNA $(5 \mu \mathrm{l})$ was added to a reaction mixture containing $0.25 \mu \mathrm{M}$ of the forward and reverse primer, $0.25 \mu \mathrm{M}$ probe, $2.75 \mathrm{mM} \mathrm{MnCl} 2,7.5 \mu \mathrm{l} \mathrm{Kit}$ and $0.2 \mu \mathrm{l}$ RNAsin (RNAsin, $40 \mathrm{U} / \mu \mathrm{l}$; Promega Benelux, Leiden, Netherlands) in a final volume of $20 \mu \mathrm{l}$.

Thermocycling conditions of the RRT-PCR were: $20 \mathrm{~s} 98^{\circ} \mathrm{C}, 20 \min 61^{\circ} \mathrm{C}, 30 \mathrm{~s} 95^{\circ} \mathrm{C}$, $\left(1 \mathrm{~s} 95^{\circ} \mathrm{C}, 10 \mathrm{~s} 61^{\circ} \mathrm{C}, 15 \mathrm{~s} 72^{\circ} \mathrm{C}\right) \times 45$ followed by $30 \mathrm{~s} 40^{\circ} \mathrm{C}$ and storage at $4^{\circ} \mathrm{C}$. Amplification was monitored real time by OD530/OD640 ratio using software version 4.05 (Roche Diagnostics Nederland) and expressed as $\mathrm{Cp}$. Cp is defined by the software version 4.05 (Roche Diagnostics Nederland). Briefly, $\mathrm{Cp}$ is the cycler number by which the line of the maximal increase of OD530/OD640 ratio is crossing the X-axis. Positive controls were included containing different virus dilutions of BTV1 grown on BHK21 cells in DMEM with $5 \%$ fetal bovine serum and diluted in the same growth medium. DNAse-free phosphate-buffered saline (PBS) solution was used as negative control.

\section{Results}

BTV8 in ixodid ticks

Variable amounts of blood were ingested by each of the 24 female ticks during capillary feeding as demonstrated by an increase in weight which ranged between 1.8 and 74,2 $\mathrm{mg}$. BTV8 was detected by PCR in 20 out of $24(83.3 \%)$ female ticks infected by capillary feeding (Table 1). There was no obvious correlation between the amount of blood ingested and the PCR-results. The virus was found in the gut, ovaries, salivary glands, Malpighian tubules as well as in the remaining tissues derived from I. ricinus, I. hexagonus, $D$. reticulatus and $R$. bursa ticks, between 3 and 15 days after feeding on BTV8-containing blood. Virus was also detected in the ovaries of 15 out of $24(62.5 \%)$ of female ticks of all four species tested (Table 1). Several engorged females were allowed to lay eggs. Larvae which hatched from eggs derived from six D. reticulatus females and from six $R$. bursa 
Table 1 Infection of female ixodid ticks with BTV8 by capillary feeding

\begin{tabular}{|c|c|c|c|c|c|c|c|c|}
\hline $\begin{array}{l}\text { Tick ID } \\
\text { number }\end{array}$ & $\begin{array}{l}\text { Days } \\
\text { post- } \\
\text { feeding }\end{array}$ & $\begin{array}{l}\text { Species of } \\
\text { tick }\end{array}$ & $\begin{array}{l}\text { Bloodmeal } \\
(\mathrm{mg})^{\mathrm{a}}\end{array}$ & $\begin{array}{l}\text { Gut } \\
(\mathrm{Cp})^{\mathrm{b}}\end{array}$ & $\begin{array}{l}\text { Ovaries } \\
\text { (Cp) }\end{array}$ & $\begin{array}{l}\text { Salivary } \\
\text { glands (Cp) }\end{array}$ & $\begin{array}{l}\text { Malpighian } \\
\text { tubules (Cp) }\end{array}$ & $\begin{array}{l}\text { Remaining } \\
\text { tissue }(\mathrm{Cp})\end{array}$ \\
\hline BT 20 & 3 & D. reticulatus & 4.3 & 27.27 & $-^{\mathrm{c}}$ & - & - & - \\
\hline BT 23 & 3 & & 19.0 & 27.17 & - & - & - & 26.87 \\
\hline BT 24 & 3 & & 74.2 & 25.87 & 29.50 & 30.44 & 32.70 & - \\
\hline BT 187 & 11 & & 33.2 & 28.03 & 30.98 & 30.22 & 32.70 & - \\
\hline BT 228 & 2 & Ixodes ricinus & 44.8 & 30.47 & 30.70 & - & 31.88 & 28.75 \\
\hline BT 1 & 5 & & 20.1 & 29.81 & - & - & 35.72 & 28.90 \\
\hline BT 77 & 6 & & 49.3 & 28.32 & 30.84 & 31.06 & - & 27.85 \\
\hline BT 79 & 6 & & 38.0 & 28.73 & 30.3 & - & - & 27.62 \\
\hline BT 107 & 7 & & 75.1 & 29.03 & 29.66 & 33.00 & 36.25 & 27.64 \\
\hline BT 108 & 7 & & 74.2 & 28.27 & 30.53 & 30.54 & - & 26.80 \\
\hline BT 109 & 7 & & 5.5 & 30.75 & 31.56 & - & 33.22 & 27.67 \\
\hline BT 175 & 12 & & 68.1 & 32.60 & 34.19 & 33.88 & 34.46 & 28.87 \\
\hline BT 95 & 13 & & 25.6 & 28.71 & 30.95 & 33.06 & 31.26 & 29.03 \\
\hline BT 97 & 13 & & 19.7 & 29.86 & 31.86 & 31.30 & 37.00 & 27.21 \\
\hline BT 143 & 15 & & 35.8 & 28.96 & 29.65 & - & - & 29.42 \\
\hline BT 166 & 14 & I. hexagonus & 36.9 & 30.18 & - & 34.77 & 33.99 & - \\
\hline BT 167 & 14 & & 42.4 & 33.60 & 31.53 & 32.68 & 34.02 & 29.77 \\
\hline BT 147 & 15 & & 7.8 & 32.44 & & 31.73 & - & - \\
\hline BT 117 & 7 & R. bursa & 16.7 & - & - & - & - & - \\
\hline BT 119 & 7 & & 2.5 & - & - & - & - & - \\
\hline BT 120 & 7 & & 1.80 & - & 30.65 & 35.24 & - & 26.74 \\
\hline BT 160 & 14 & & 18.6 & 29.19 & 31.58 & 32.61 & 31.04 & 28.93 \\
\hline BT 161 & 14 & & 9.9 & 30.12 & - & - & 33.45 & - \\
\hline BT 172 & 19 & & 3.1 & - & - & - & - & - \\
\hline
\end{tabular}

\footnotetext{
${ }^{a}$ The amount of ingested blood was determined by weighting each tick before and after capillary feeding

b $\mathrm{Cp}$, Crossing point, see "Materials and methods"

c Negative
}

ticks were negative for BTV8. Eggs produced by one of the I. hexagonus female ticks were also negative.

Male ticks ingested only very small amounts of blood through the capillaries, with a maximum of $3 \mathrm{mg}$. Despite these small amounts of ingested blood, 6 out of $12(50 \%)$ D. reticulatus males contained BTV8 in their gut, testis, salivary glands, Malpighian tubules and in their remaining tissues (Table 2). Also, two I. ricinus males contained virus in their gut, testis, salivary glands and also in the remaining tissues. One D. reticulatus tick contained virus in its salivary glands on day 5 after capillary feeding, whereas the salivary glands of one I. ricinus tick was positive on day 8 after feeding (Table 2).

Nymphs of D. reticulatus, $R$. bursa and I. hexagonus were also capillary fed on BTV8containing blood. After the nymphs had moulted into the adult stage, they were also tested for BTV8. The gut of one out of two I. hexagonus adults contained BTV8 on 21 days after capillary feeding. 
Table 2 Infection of male ixodid ticks by BTV8 by capillary feeding

\begin{tabular}{llllllll}
\hline Number & $\begin{array}{l}\text { Days } \\
\text { post- } \\
\text { feeding }\end{array}$ & Species & $\begin{array}{l}\text { Gut } \\
(\mathrm{Cp})^{\mathrm{a}}\end{array}$ & $\begin{array}{l}\text { Testes } \\
(\mathrm{Cp})\end{array}$ & $\begin{array}{l}\text { Salivary glands } \\
(\mathrm{Cp})\end{array}$ & $\begin{array}{l}\text { Malpighian } \\
\text { tubules (Cp) }\end{array}$ & $\begin{array}{l}\text { Remaining } \\
\text { tissue (Cp) }\end{array}$ \\
\hline BT 41 & 5 & D. reticulatus & $-^{\mathrm{b}}$ & - & - & - & - \\
BT 42 & 5 & & 32.85 & - & - & 35.67 & 28.86 \\
BT 43 & 5 & & - & - & - & - & 26.55 \\
BT 44 & 5 & & - & - & 33.92 & 34.12 & - \\
BT 46 & 5 & & - & - & - & - & - \\
BT 35 & 12 & & 32.55 & 33.56 & - & - & 29.65 \\
BT 36 & 12 & & - & - & - & - & - \\
BT 40 & 12 & & - & - & - & 35.70 & - \\
BT 45 & 12 & & - & - & - & ND & - \\
BT 37 & 16 & & - & - & - & - & - \\
BT 39 & 16 & & - & - & - & - & 26.95 \\
BT 47 & 16 & & - & - & - & - & - \\
BT 86 & 8 & I. ricinus & 40.00 & 36.90 & 35.96 & - & 32.19 \\
BT 87 & 8 & & 36.60 & - & - & - & 30.58 \\
\hline
\end{tabular}

a $\mathrm{Cp}$, Crossing point, see "Materials and methods"

b Negative

ND, not done

Table 3 Transstadial passage of BTV8 from nymphs to adult ixodid ticks after capillary feeding

\begin{tabular}{|c|c|c|c|c|c|c|c|c|c|}
\hline $\begin{array}{l}\text { Tick ID } \\
\text { number }\end{array}$ & $\begin{array}{l}\text { Days } \\
\text { post- } \\
\text { feeding }\end{array}$ & Tick species & $\begin{array}{l}\text { Male/ } \\
\text { female }\end{array}$ & $\begin{array}{l}\text { Blood- } \\
\text { meal } \\
(\mathrm{mg})^{\mathrm{a}}\end{array}$ & $\begin{array}{l}\text { Gut } \\
(\mathrm{Cp})^{\mathrm{b}}\end{array}$ & $\begin{array}{l}\text { Ovaries/ } \\
\text { testes } \\
(\mathrm{Cp})\end{array}$ & $\begin{array}{l}\text { Salivary } \\
\text { glands } \\
(\mathrm{Cp})\end{array}$ & $\begin{array}{l}\text { Malpighian } \\
\text { tubules } \\
\text { (Cp) }\end{array}$ & $\begin{array}{l}\text { Remaining } \\
\text { tissue }(\mathrm{Cp})\end{array}$ \\
\hline BT 72 & 68 & D. reticulatus & $\mathrm{F}$ & 4.0 & $-^{\mathrm{c}}$ & - & - & - & - \\
\hline BT 140 & 21 & I. hexagonus & $\mathrm{F}$ & 1.0 & - & - & - & - & - \\
\hline BT 141 & 21 & & M & 0.2 & 34.04 & - & - & - & - \\
\hline BT 61 & 39 & R. bursa & $\mathrm{F}$ & 4.1 & - & - & - & - & - \\
\hline BT 62 & 39 & & $\mathrm{~F}$ & 1.4 & - & - & - & - & - \\
\hline BT 66 & 39 & & $\mathrm{~F}$ & 0.6 & - & - & - & - & - \\
\hline BT 56 & 40 & & $\mathrm{~F}$ & 4.2 & - & - & - & - & - \\
\hline
\end{tabular}

\footnotetext{
${ }^{a}$ The amount of ingested blood was determined by weighting each tick before and after capillary feeding

b Cp, Crossing point, see "Materials and methods"

c Negative
}

The other ticks, one $D$. reticulatus female tick and 4 female $R$. bursa, were negative (Table 3).

Furthermore, when I. ricinus female ticks fed on artificial membranes, two ticks acquired BTV8, which could be detected 15 days later in their gut, ovary, salivary glands and Malpighian tubules (Table 5).

Finally, laboratory-reared negative control ticks that were not exposed to BTV8 and artificial feeding were also included in the above described experiments as negative controls. All such control ticks were PCR-negative for BTV8. 
Table 4 Transovarial passage of BTV8 in Ornithodoros ticks after feeding on membranes

\begin{tabular}{llllllll}
\hline $\begin{array}{l}\text { Tick ID } \\
\text { Number }\end{array}$ & $\begin{array}{l}\text { Days post- } \\
\text { feeding }\end{array}$ & $\begin{array}{l}\text { Salivary } \\
\text { glands }(\mathrm{Cp})^{\mathrm{a}}\end{array}$ & $\begin{array}{l}\text { Gut } \\
(\mathrm{Cp})\end{array}$ & $\begin{array}{l}\text { Ovaries/ } \\
\text { Testes }(\mathrm{Cp})\end{array}$ & $\begin{array}{l}\text { Malpighian } \\
\text { tubules }(\mathrm{Cp})\end{array}$ & $\begin{array}{l}\text { Remaining } \\
\text { tissue }(\mathrm{Cp})\end{array}$ & $\begin{array}{l}\text { Eggs } \\
(\mathrm{Cp})\end{array}$ \\
\hline BT 210 & 26 & - & 30.80 & 32.29 & $-{ }^{\mathrm{b}}$ & 31.42 & - \\
BT 211 & 26 & 32.89 & 29.68 & 30.54 & - & 31.52 & No eggs \\
BT 212 & 26 & - & 26.95 & 32.67 & 34.69 & 32.18 & 31.72 \\
BT 213 & 26 & 33.52 & 30.35 & 32.94 & - & 30.21 & No eggs \\
\hline
\end{tabular}

" Cp, Crossing point, see "Materials and methods"

b Negative

BTV8 in soft ticks

Four Ornithodoros savignyi females fed on artificial membranes were dissected 26 days after feeding. It was found that the ovaries, gut and remaining tissues of all 4 ticks contained BTV8. In addition, two out of four ticks were positive in the salivary glands. Interestingly, eggs produced by one female Ornithodoros tick were also infected by BTV8 (Table 4), but BTV8 could not be detected in the offspring ( $\mathrm{N}_{1}$ nymphs), which emerged from these eggs.

\section{Discussion}

Bluetongue virus serotype 8 was taken up by 4 different species of ixodid ticks, wherein the virus was able to maintain itself, pass through the gut barrier and spread via the haemolymph into the salivary glands, ovaries and testes. Colonisation of the salivary glands is significant, since it would imply that the virus could be transmitted via the saliva when male ticks are feeding on the next host. The successful passage of the virus between stages of the same tick was demonstrated in the case of I. hexagonus, during moulting of nymphs to the adult stage. The next step would be to feed such ticks wherein the infection would move to the salivary gland and subsequently transmitted through the saliva. In this study, the infection had reached the gut but not (yet?) the salivary gland of I. hexagonus (Table 3). However, in two other male ticks, (I. ricinus and D. reticulatus) BTV8 was detected in the salivary glands after capillary feeding (Table 2).

It is likely that these ticks are also able to transmit the infection fed on a susceptible host or on an artificial membrane in vitro. A further step in this direction was taken by conducting acquisition experiments with $I$. ricinus ticks which were allowed to feed voluntary on artificial membranes rather than being force-fed through capillaries. The predominant tick on livestock through much of North-West Europe I. ricinus is able to take up BTV8 and pass on onto several internal organs including the salivary glands (Table 5).

Further experiments are required to demonstrate whether (artificially) infected ticks are able to transmit BTV either onto a susceptible host or into non-infected blood during artificial membrane feeding.

Transovarial passage and infection of the next generation of ticks could not be demonstrated in D. reticulatus, $R$. bursa and I. hexagonus: larvae derived from the adult ticks were all PCR-negative. Unfortunately, fungal infections which developed in most I. ricinus prohibited further testing of the progeny of this tick. 
Table 5 Infection of Ixodes ricinus females with BTV8 by membrane feeding

\begin{tabular}{llllllll}
\hline $\begin{array}{l}\text { Tick ID } \\
\text { number }\end{array}$ & $\begin{array}{l}\text { Days post- } \\
\text { feeding }\end{array}$ & $\begin{array}{l}\text { Tick } \\
\text { species }\end{array}$ & $\begin{array}{l}\text { Gut } \\
(\mathrm{Cp})^{\mathrm{a}}\end{array}$ & $\begin{array}{l}\text { Ovaries } \\
(\mathrm{Cp})\end{array}$ & $\begin{array}{l}\text { Salivary } \\
\text { glands (Cp) }\end{array}$ & $\begin{array}{l}\text { Malpighian } \\
\text { tubules (Cp) }\end{array}$ & $\begin{array}{l}\text { Remaining } \\
\text { tissue (Cp) }\end{array}$ \\
\hline IR 1 & 15 & I. ricinus & 26.32 & $-^{\text {b }}$ & 34.78 & 32.74 & 26.3 \\
IR 2 & 15 & I. ricinus & 28.19 & 28.79 & 33.51 & 29.59 & 24.75 \\
\hline
\end{tabular}

a $\mathrm{Cp}$, Crossing point, see "Materials and methods"

b Negative

The soft tick $O$. savignyi was successfully infected with BTV8-containing blood by feeding on an artificial membrane. BTV8 was detected in various tissues including salivary glands for up to 26 days (Table 4). Since soft ticks do feed multiple times during the same life stage, virus contained in the salivary glands could be transmitted during the same life cycle stage. The infection was also found to pass through the ovaries into the eggs. This finding confirms the possible vectorial capacity of soft ticks for BTV, since transmission of BTV was already reported for $O$. coriaceus (Stott et al., 1985). Soft ticks do not play a role in the epidemiology of the disease in Europe, since these do not occur on livestock in this area, but could play a role in the introduction of bluetongue virus in North-West Europe. In this study soft ticks served as a positive control species. In contrast to soft ticks, 3 of the species of hard ticks used in this study are prevalent on the ruminant population throughout large areas of North-West Europe where the current bluetongue outbreaks occur.

On the other hand, small numbers of adult Culicoides vectors were caught throughout the mild winter of 2006-2007 (Losson et al. 2007). A small fraction of the infected adult Culicoides population may survive long enough during these winters to bridge the gap between transmission seasons. BTV could also persist in the ruminant population during the winter, whether by chronic or latent infection of some individuals whereas transmission across the placenta from mother to foetus is another possibility.

Finally, the long survival period of ticks off hosts makes them interesting candidates to serve as (additional) reservoir for BTV. The observations presented in this paper would justify further investigations for this hypothesis.

\section{Conclusion}

Bluetongue virus serotype 8 can survive for at least 21 days in hard ticks and up to 26 days in the soft tick $O$. savignyi. BTV can pass the gut barrier to other organs of the tick. In this way BTV can be passed trans-stadially and intra-stadially in male Ixodes ticks. It can be passaged transovarially in $O$. savignyi. Further research is necessary to determine whether these ticks are able to transmit BTV to susceptible hosts.

Acknowledgments This collaborative project was financially supported by Central Veterinary Institute of Wageningen UR (CVI), Lelystad, The Netherlands. Dr. Armin Elbers (CVI, Lelystad) is thanked for his encouragement to undertake this study.

Open Access This article is distributed under the terms of the Creative Commons Attribution Noncommercial License which permits any noncommercial use, distribution, and reproduction in any medium, provided the original author(s) and source are credited. 


\section{References}

Booth T, Steele GM, Marriot AC, Nuttall PA (1991) Dissemination, replication, and trans-stadial persistence of Dugbe virus (Nairovirus, Bunyaviridae) in the tick vector Amblyomma variegatum. Am J Trop Med Hyg 45:146-157

Burgdorfer W (1957) Artificial feeding of ixodid ticks for studies on the transmission of disease agents. J Infect Dis 100:212-214

Dijkstra E, van der Ven IJ, Meiswinkel R, Holzel DR, Van Rijn PA (2008) Culicoides chiopterus as a potential vector of bluetongue virus in Europe. Vet Rec 162:422

Enserink M (2006) Emerging infectious diseases. During a hot summer, bluetongue virus invades northern Europe. Science 313:1218-1219

Estrada-Peña A, Bouattour A, Camicas JL, Walker AR (2004) Ticks of domestic animals in the Mediterranean Region. A guide to identification of species. University of Zaragoza, Spain

Hoogstraal H (1956) Ornithodoros savignyi. In: African Ixodoidea ticks of the Sudan. vol. 1, Department of the Navy. Bureau of Medicine and Surgery pp 191-199

Inokuma H, Kemp DH (1998) Establishment of Boophilus microplus infected with Babesia bigemina by using in vitro tube feeding technique. J Vet Med Sci 60:509-512

Kröber T, Guerin PM (2007) In vitro feeding assays for hard ticks. Trends Parasitol 23:445-449

Labuda M, Nuttall PA (2004) Tick-borne viruses. Parasitology 129:S221-S245

Losson B, Mignon B, Paternostre J, Madder M, De Deken R (2007) Biting midges overwintering in Belgium. Vet Rec 160:451-452

Luedke AJ, Jochim MM, Bowne JG (1965) Preliminary bluetongue transmission with the sheep ked Melophagus ovinus (L.). Can J Comp Med Vet Sci 29:229-231

Matsumoto K, Brouqui P, Raoult D, Parola P (2005) Experimental infection models of ticks of the Rhipicephalus sanguineus group with Rickettsia conorii. Vector Borne Zoonotic Dis 5:363-372

Meiswinkel R, van Rijn P, Leijs P, Goffredo M (2007) Potential new Culicoides vector of bluetongue virus in northern Europe. Vet Rec 161:564-565

Mellor PS (1990) The replication of bluetongue virus in Culicoides vectors. Curr Top Microbiol Immunol 162:143-161

Mellor PS, Boorman J (1995) The transmission and geographical spread of African horse sickness and bluetongue viruses. Ann Trop Med Parasitol 89:1-15

Nevill EM (1971) Cattle and Culicoides biting midges as possible overwintering hosts of bluetongue virus. Onderstepoort J Vet Res 38:65-72

Nijhof AM, Bodaan C, Postigo M, Nieuwenhuijs H, Opsteegh M, Franssen L, Jebbink F, Jongejan F (2007) Ticks and associated pathogens collected from domestic animals in the Netherlands. Vector Borne Zoonotic Dis 7:585-595

Rechav Y, Zyzak M, Fielden LJ, Childs JE (1999) Comparison of methods for introducing and producing artificial infection of ixodid ticks (Acari: Ixodidae) with Ehrlichia chaffeensis. J Med Entomol 36: 414-419

Schwan E, Hutton D, Shields KJB, Townson S (1991) Artificial feeding and successful reproduction in Ornithodoros moubata moubata (Murray, 1877) (Acarina: Argasidae). Exp Appl Acarol 13:107-115

Schwartz-Cornil I, Mertens PP, Contreras V, Hemati B, Pascale F, Breard E, Mellor PS, Maclachlan NJ, Zientara S (2008) Bluetongue virus: virology, pathogenesis and immunity. Vet Res 39:46

Stott JL, Osburn BI, Alexander L (1985) Ornithodoros coriaceus (pajaroello tick) as a vector of bluetongue virus. Am J Vet Res 46:1197-1199

Verwoerd DW, Erasmus BJ (2004) Bluetongue. In: Infectious diseases of livestock. vol. 2, Oxford University Press Southern Africa, pp 1201-1220

Wilson A, Darpel K, Mellor PS (2008) Where does bluetongue virus sleep in the winter? PLoS Biol 6(8):1612-1617 